\title{
Reversal of Cyclic AMP-Mediated Intestinal Secretion by Ethacrynic Acid
}

\author{
Qais Al-Awqati, Mrchael Field, and William B. Greenough, III \\ From the Department of Medicine, Johns Hopkins University School of \\ Medicine and Johns Hopkins Hospital, Baltimore, Maryland 21205 and the \\ Department of Medicine, Harvard Medical School, and Gastrointestinal Unit \\ of the Department of Medicine, Beth Israel Hospital, \\ Boston, Massachusetts 02115
}

A в S T RACT Ethacrynic acid (EA) has been reported to reduce cholera toxin-induced intestinal fluid secretion in the intact animal. We explored the nature of this inhibition in vitro by measuring unidirectional, transmural fluxes of ${ }^{22} \mathrm{Na}$ and ${ }^{38} \mathrm{Cl}$ across isolated rabbit ileal mucosa. Under control conditions (short-circuited mucosa bathed in bicarbonate-Ringer), there was net absorption of $\mathrm{Na}$ and $\mathrm{Cl}$. Theophylline $(10 \mathrm{mM})$, cyclic AMP ( $5 \mathrm{mM}$ ), and cholera toxin (added in vivo) abolished net $\mathrm{Na}$ flux and produced net $\mathrm{Cl}$ secretion. In the presence of either theophylline or cAMP, addition of $0.1 \mathrm{mM}$ EA to the serosal bathing solution abolished net $\mathrm{Cl}$ secretion and restored net $\mathrm{Na}$ absorption. Cholera toxin-treated mucosa was exposed to 0.05 and $1.0 \mathrm{mM}$ EA. The lower concentration restored net $\mathrm{Na}$ absorption but did not significantly reduce $\mathrm{Cl}$ secretion. The higher concentration abolished net transport of both $\mathrm{Na}$ and $\mathrm{Cl}$. Short-circuit current and $\mathrm{Na}$ flux measurements in the presence and absence of glucose indicated that $0.1 \mathrm{mM}$ EA does not inhibit glucose-coupled $\mathrm{Na}$ transport. Shortcircuit current measurements in the presence of $1.0 \mathrm{mM}$ EA suggested that even this concentration of EA does not inhibit glucose-coupled $\mathrm{Na}$ transport. Thus EA appears to specifically inhibit $\mathrm{Cl}$ (or $\mathrm{NaCl}$ ) secretion without inhibiting the absorptive $\mathrm{Na}$ "pump." The antisecretory effect of $0.1 \mathrm{mM} \mathrm{EA}$ does not appear to result from inhibition of adenylate cyclase since secretion stimulated by addition of $5 \mathrm{mM}$ cAMP was abolished. Furthermore, $0.1 \mathrm{mM}$ EA did not significantly reduce theophylline-augmented and cholera toxin-augmented cAMP levels in ileal mucosa. We conclude that EA interacts specifically with the active $\mathrm{Cl}$ (or $\mathrm{NaCl}$ ) se-

Dr. Al-Awqati's present address is Department of Internal Medicine, University of Iowa Hospitals, Iowa City, Iowa 52242.

Received for publication 22 June 1973 and in revised form 29 October 1973. cretory mechanism of the small intestine at a step beyond generation of $\mathrm{cAMP}$.

\section{INTRODUCTION}

Addition of adenosine $3^{\prime}, 5^{\prime}$-cyclic monophosphate (cAMP), theophylline, or cholera enterotoxin to isolated rabbit ileal mucosa results in an active secretory process characterized (in the short-circuited state) by net $\mathrm{Cl}$ secretion and by inhibition of net $\mathrm{Na}$ absorption $(1,2)$. Both theophylline and cholera toxin increase the concentration of cAMP in the mucosa, the former by inhibiting cyclic nucleotide phosphodiesterase and the latter by stimulating adenylate cyclase (3-5). Furthermore, changes in adenylate cyclase activity and cAMP concentration correlate closely with changes in ion transport $(5,6)$. cAMP appears, therefore, to be the mediator of these effects. Studies of ion influx across the luminal border indicate that these effects are due, at least in part, to inhibition of a coupled component of $\mathrm{Na}$ and $\mathrm{Cl}$ influx $(7,8)$. At present it is unclear whether cAMP also stimulated active secretion of ions or only unmasks a pre-existing secretion by inhibiting their absorption. It also remains to be resolved conclusively whether the active secretory process is for anion alone $\left(\mathrm{Cl}\right.$ and possibly also $\mathrm{HCO}_{3}$ ) or for anion coupled directly to $\mathrm{Na}(2,9)$.

Ethacrynic acid $(E A)^{1}$ has been shown to inhibit cholera toxin-induced intestinal fluid secretion in the dog (10). This does not promise to be of therapeutic value since the diuretic effect of $\mathrm{EA}$ outweighs its antidiarrheal effect. Nonetheless, the inhibition by EA of cholera toxin-induced secretion is of theoretical in-

\footnotetext{
${ }^{1}$ Abbreviations used in this paper: EA, ethacrynic acid; $\mathrm{J}_{\text {net }}$, net flux; $\mathrm{J}_{\mathrm{ms}}$, mucosal to serosal flux; $\mathrm{J}_{\mathbf{s m}}$, serosal to mucosal flux; SCC, short-circuit current.
} 
TABLE I

Effects of EA on SCC and Electrical Resistunce

\begin{tabular}{|c|c|c|c|c|c|c|}
\hline \multirow[b]{2}{*}{ Additions } & \multirow[b]{2}{*}{ EA } & \multirow[b]{2}{*}{$n$} & \multicolumn{2}{|c|}{ SCC } & \multicolumn{2}{|c|}{ Resistance } \\
\hline & & & $-\mathrm{EA}$ & $+\mathrm{EA}$ & $-\mathrm{EA}$ & $+\mathrm{EA}$ \\
\hline & $m .1 /$ & & \multicolumn{2}{|c|}{$\mu e q / h \cdot \mathrm{cm}^{2}$} & \multicolumn{2}{|c|}{$\Omega \cdot \mathrm{cm}^{2}$} \\
\hline None & 0.05 & 7 & $2.4 \pm 0.2$ & $1.6 \pm 0.2^{*}$ & $36 \pm 1$ & $36 \pm 1$ \\
\hline None & 0.10 & 6 & $2.5 \pm 0.3$ & $1.2 \pm 0.3^{*}$ & $35 \pm 2$ & $32 \pm 2$ \\
\hline None & 1.00 & 7 & $2.5 \pm 0.3$ & $1.2 \pm 0.2^{*}$ & $47 \pm 3$ & $34 \pm 3^{*}$ \\
\hline Theophylline, $10 \mathrm{mM}$ & 0.10 & 6 & $4.4 \pm 0.4$ & $2.4 \pm 0.2^{*}$ & $46 \pm 3$ & $35 \pm 2^{*}$ \\
\hline cAMP, $5 \mathrm{mM}$ & 0.10 & 6 & $3.7 \pm 0.3$ & $3.0 \pm 0.2^{*}$ & $54 \pm 4$ & $35 \pm 2^{*}$ \\
\hline Cholera toxin & 0.05 & 5 & $4.3 \pm 0.3$ & $3.2 \pm 0.3^{*}$ & $45 \pm 2$ & $41 \pm 2^{*}$ \\
\hline Cholera toxin & 0.10 & 4 & $4.6 \pm 0.2$ & $3.1 \pm 0.2^{*}$ & $45 \pm 2$ & $41 \pm 2^{*}$ \\
\hline Cholera toxin & 1.00 & 6 & $2.8 \pm 0.2$ & $1.2 \pm 0.1^{*}$ & $68 \pm 2$ & $49 \pm 2^{*}$ \\
\hline
\end{tabular}

Values are means \pm 1 SE. $n$ refers to the number of animals. Theophylline and cAMP added to serosal bathing solution 20-30 min after tissues mounted. Cholera toxin added to isolated ileal loops in vivo (purified toxin $10 \mu \mathrm{g} / \mathrm{loop}$ for 0.05 and $0.10 \mathrm{mM} \mathrm{EA}$ additions and crude toxin, $100 \mathrm{mg} / \mathrm{loop}$ for $1.0 \mathrm{mM}$ $\mathrm{EA}$ addition) and tissues then mounted in vitro $4 \mathrm{~h}$ later. EA added to serosal bathing solution $15 \mathrm{~min}$ after theophylline or cAMP or $30 \mathrm{~min}$ after mounting cholera toxin-treated tissues in vitro. SCC and resistance values are average values for the period 20-30 min after addition of EA or the comparable period for control tissues. These are average values, therefore, for the same period over which $\mathrm{Na}$ and $\mathrm{Cl}$ fluxes were determined (see Table II). All results for the presence and absence of EA represent paired data on tissues from the same animals. Resistances were measured by pulsing in $100 \mu \mathrm{A}$ of current and measuring the voltage deflection. It had previously been determined that the $\mathrm{I}-\mathrm{V}$ relationship is linear in these ranges. ${ }^{*} P<0.05$ for paired difference from control $(-\mathrm{EA})$.

terest with respect to the mechanism for cAMP-induced secretion in the intestine and, also more generally, with respect to the mechanism by which EA alters ion transport in other tissues, especially the kidney. We have therefore examined the antisecretory effect of EA in vitro, utilizing isolated rabbit ileal mucosa.

\section{METHODS}

Segments of distal ileum were obtained from New Zealand white, male rabbits that weighed between 2 and $3.5 \mathrm{~kg}$ and were fed a standard rabbit chow ad lib. The methods for isolating mucosa, short-circuiting and determining ion fluxes in vitro with ${ }^{22} \mathrm{Na},{ }^{24} \mathrm{Na}$, and ${ }^{38} \mathrm{Cl}$ have been previously described (11).

Briefly, ileum was stripped of muscularis and serosa and clamped between two Lucite half-chambers attached to two reservoirs maintained at $37^{\circ} \mathrm{C}$. The medium bathing the membrane contained, in millimoles/liter $\mathrm{Na}, 141 ; \mathrm{Ca}, 1.25$; $\mathrm{K}, 10 ; \mathrm{Mg}, 1.1 ; \mathrm{Cl}, 127 ; \mathrm{HCO}_{3}, 25 ; \mathrm{HPO}_{4}, 1.65 ; \mathrm{H}_{2} \mathrm{PO}_{4}$, 0.3 ; and $\mathrm{pH}, 7.4$. The medium was continuously gassed by $95 \% \mathrm{O}_{2}-5 \% \mathrm{CO}_{2}$. All experiments were done in the short-circuited state. Unidirectional $\mathrm{Na}$ and $\mathrm{Cl}$ fluxes were determined in most instances by adding ${ }^{22} \mathrm{Na}$ and ${ }^{38} \mathrm{Cl}$ to one side of the tissue and measuring their steady-state rates of transfer to the other side. $20 \mathrm{~min}$ were allowed for steady state to be reached (11). In one set of experiments bidirectional $\mathrm{Na}$ fluxes were measured on each tissue with ${ }^{2} \mathrm{Na}$ and ${ }^{*} \mathrm{Na}$. The net flux $\left(\mathrm{J}_{\text {net }}\right)$ was calculated as the mucosal to serosal flux $\left(\mathrm{J}_{\mathrm{ms}}\right)$ minus the serosal to mucosal flux $\left(\mathrm{J}_{\mathrm{sm}}\right)$. Unless otherwise stated no glucose was present in the mucosal medium. Glucose $(7.5-10 \mathrm{mM})$ was always added to the serosal medium and an equimolar amount of mannitol was added to the mucosal medium. In some experiments, four pieces of ileum were mounted from the same animal and fluxes were measured simultaneously under experimental and control conditions.

In cholera toxin experiments, toxin was introduced into isolated ileal loops of anesthetized animals and tissues from these or control loops were mounted in vitro $4 \mathrm{~h}$ later as previously described (2).

For determining the effects of cholera toxin, theophylline, and EA on tissue cAMP levels, sheets of mucosa were stripped from rabbit ileum (4), cut into sections of approximately $50 \mathrm{mg}$ wet weight, and incubated with shaking at $37^{\circ} \mathrm{C}$ in suitable media. At the end of incubations, tissues were quickly transferred to conical centrifuge tubes containing $5 \mathrm{ml}$ of ice-cold $5 \%$ trichloroacetic acid (TCA) with $0.8 \mathrm{mCi}$ of $\left[{ }^{3} \mathrm{H}\right]$-cAMP $(24 \mathrm{Ci} / \mathrm{mmol})$ as a recovery marker. The tissues were homogenized with a Teflon pestle in a glass homogenizer and the TCA precipitates were then centrifuged at $4,000 \mathrm{~g}$ for $20 \mathrm{~min}$ at $4^{\circ} \mathrm{C}$. The supernates were decanted into $40-\mathrm{ml}$ conical centrifuge tubes and $0.5 \mathrm{ml}$ of $1 \mathrm{~N} \mathrm{HCl}$ was then added. The TCA was extracted five times with $10 \mathrm{ml}$ of diethyl ether, after which the samples were evaporated to dryness at $50^{\circ} \mathrm{C}$ using an Evapo-Mix evaporator (Buchler Instruments, Div., Nuclear-Chicago, Corp., Fort Lee, N. J.). The residues were then dissolved in $2.0 \mathrm{ml}$ of $50 \mathrm{mM}$ sodium acetate buffer, $\mathrm{pH}$ 4.0. Recoveries of cAMP extracted from the tissues were determined by counting $0.5-\mathrm{ml}$ aliquots in 10 $\mathrm{ml}$ of Bray's solution (12) and comparing the results with those obtained by counting aliquots of the original recovery marker diluted in $0.5 \mathrm{ml}$ of the acetate buffer. Each sample was assayed in duplicate for cAMP levels by the proteinkinase-binding method described by Gilman (13). The TCA precipitates were dissolved overnight in $5 \mathrm{ml}$ of $1 \mathrm{~N}$ 
TABLE II

Effects of EA on $\mathrm{Na}$ and $\mathrm{Cl}$ Fluxes

\begin{tabular}{|c|c|c|c|c|c|c|c|c|}
\hline & \multirow[b]{3}{*}{ EA } & \multirow[b]{3}{*}{$n$} & \multicolumn{6}{|c|}{ Fluxes } \\
\hline & & & \multicolumn{3}{|c|}{$\mathrm{Na}$} & \multicolumn{3}{|c|}{$\mathrm{Cl}$} \\
\hline & & & $\mathrm{J}_{\mathrm{ms}}$ & $\mathrm{J}_{\mathrm{mm}}$ & $J_{\text {net }}$ & $J_{\mathbf{m}}$ & $J_{\text {am }}$ & $J_{\text {not }}$ \\
\hline & $m M$ & & & $\mu e q / h \cdot \mathrm{cm}^{2}$ & & & $\mu e q / h \cdot \mathrm{cm}^{2}$ & \\
\hline \multirow[t]{3}{*}{ None } & 0 & 23 & $13.9 \pm 0.4$ & $12.3 \pm 0.5$ & $1.6 \pm 0.3$ & $9.4 \pm 0.5$ & $8.6 \pm 0.4$ & $1.3 \pm 0.5$ \\
\hline & 0.05 & 7 & $13.9 \pm 0.3$ & $12.2 \pm 0.4$ & $1.6 \pm 0.3$ & $7.2 \pm 0.9$ & $6.2 \pm 0.6$ & $1.0 \pm 0.3$ \\
\hline & 1.00 & 6 & $10.4 \pm 0.7$ & $11.2 \pm 1.0$ & $-0.8 \pm 1.2$ & $7.2 \pm 0.5$ & $7.3 \pm 0.8$ & $-0.1 \pm 1.0$ \\
\hline \multirow[t]{2}{*}{ Theophylline, $10 \mathrm{mM}$} & 0 & 6 & $10.8 \pm 0.7$ & $11.2 \pm 0.6$ & $-0.4 \pm 0.6$ & $6.8 \pm 0.9$ & $9.8 \pm 0.8$ & $-3.0 \pm 0.7$ \\
\hline & 0.10 & 5 & $13.3 \pm 1.1$ & $11.1 \pm 1.2$ & $2.2 \pm 0.4^{*}$ & $6.6 \pm 0.7$ & $6.0 \pm 0.6^{*}$ & $0.6 \pm 0.9^{*}$ \\
\hline \multirow[t]{2}{*}{ cAMP, $5 \mathrm{mM}$} & $\mathbf{0}$ & 6 & $7.6 \pm 0.7$ & $8.4 \pm 0.8$ & $-0.8 \pm 0.7$ & $5.7 \pm 0.6$ & $8.6 \pm 0.4$ & $-2.9 \pm 0.5$ \\
\hline & 0.10 & 6 & $12.0 \pm 0.9 \ddagger$ & $10.4 \pm 0.7$ & $1.9 \pm 0.8 \ddagger$ & $7.4 \pm 0.7 \ddagger$ & $7.9 \pm 0.5$ & $-0.5 \pm 0.3 \ddagger$ \\
\hline \multirow[t]{2}{*}{ Cholera toxin§ } & 0 & 16 & $9.4 \pm 0.6$ & $9.8 \pm 0.7$ & $-0.4 \pm 0.4$ & $5.8 \pm 0.4$ & $8.3 \pm 0.5$ & $-2.5 \pm 0.3$ \\
\hline & 1.00 & 6 & $12.5 \pm 1.3^{*}$ & $12.4 \pm 0.7^{*}$ & $0.1 \pm 1.0$ & $10.1 \pm 1.0^{*}$ & $10.5 \pm 0.7^{*}$ & $-0.4 \pm 0.9^{*}$ \\
\hline \multirow[t]{2}{*}{ Cholera toxin\| } & 0 & 5 & $10.8 \pm 0.4$ & $12.1 \pm 0.6$ & $-1.3 \pm 0.4$ & $6.0 \pm 0.6$ & $7.9 \pm 0.5$ & $-1.9 \pm 0.2$ \\
\hline & 0.05 & 5 & $12.7 \pm 0.9$ & $11.7 \pm 0.8$ & $1.0 \pm 0.2 \ddagger$ & $6.4 \pm 1.1$ & $7.7 \pm 0.5$ & $-1.3 \pm 1.0$ \\
\hline
\end{tabular}

Values are means $\pm 1 \mathrm{SE}$. $n$ refers to the number of animals. Fluxes measured under short-circuit condition. See legend to Table I for timing of additions and flux measurements.

* $P<0.05$ for unpaired difference from control (no EA).

$\ddagger P<0.05$ for paired difference from control (no EA). In these experiments, four tissues were prepared from one animal, one pair was used for the EA study and the other for the "control".

$\$$ Crude toxin, $100 \mathrm{mg} /$ loop.

\|l Purified toxin, $10 \mu \mathrm{g} /$ loop.

$\mathrm{NaOH}$ and the protein content was measured by the method of Lowry, Rosebrough, Farr, and Randall (14), using bovine serum albumin as a standard.

Crude cholera toxin (Wyeth Laboratories, Philadelphia, Pa., lot no. 001) was supplied by Dr. John Seal, National Institutes of Allergy and Infectious Diseases, Bethesda, Md. Purified cholera toxin was a gift of Dr. Richard A. Finkelstein, University of Texas Southwestern Medical School, Dallas, Tex. and was prepared by him as described in footnote 2. cAMP was obtained as the acid from Schwarz Bio Research Inc. (Orangeburg, N. Y.), and neutralized with $\mathrm{NaOH}$ just before use. EA (Edecrin, Merck Sharp \& Dohme, West Point, Pa.) was dissolved in bicarbonate-Ringer immediately before use.

All statistical analyses were performed using Students' $t$ test for paired and unpaired variates.

\section{RESULTS}

Effects of EA on electrical resistance and short-circuit current $(S C C)$. Addition of EA to the serosal side of the ileum had no effect on SCC or resistance at concentrations below $0.01 \mathrm{mM}$. At EA concentrations of $0.05 \mathrm{mM}$ and higher, the SCC declined quickly to reach a steady level which was $0.8-1.3 \mu \mathrm{eq} / \mathrm{h} \cdot \mathrm{cm}^{2}$ less than the control level (Table I). After prior additions of cholera toxin, theophylline, and cAMP, EA also decreased SCC, the decreases ranging from 0.7 to $2.0 \mu \mathrm{eq} / \mathrm{h} \cdot \mathrm{cm}^{2}$. EA decreased the resistance of control tissues only at the highest concentration tested $(1.0 \mathrm{mM})$ but decreased

1970. J. Infect. Dis. 121 (suppl.) : 536. the resistance of tissues treated with cholera toxin, theophylline, or cAMP at a 10 -fold lower concentration (0.1 $\mathrm{mM})$.

Effects of $\mathrm{EA}$ on $\mathrm{Na}$ and $\mathrm{Cl}$ fluxes. These results are summarized in Table II and Fig. 1. EA, at $0.1 \mathrm{mM}$ concentration, inhibited net $\mathrm{Cl}$ secretion in the presence of either cAMP $(5 \mathrm{mM})$ or theophylline $(10 \mathrm{mM})$. At $1.0 \mathrm{mM}$ concentration, EA also inhibited cholera toxininduced $\mathrm{Cl}$ secretion. At a $0.05 \mathrm{mM}$ concentration, how-

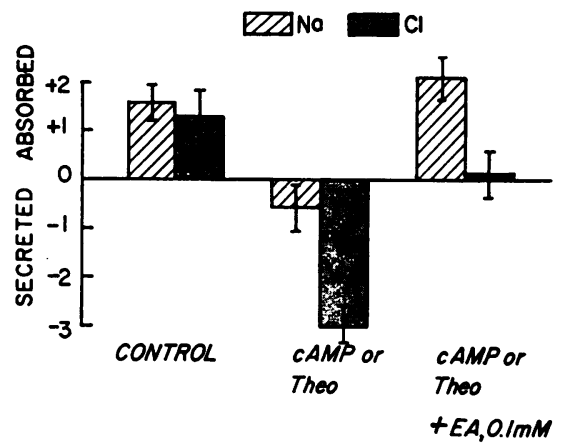

FIGURE 1 Reversal by EA of cAMP and theophylline (theo)-induced changes in net fluxes of $\mathrm{Na}$ and $\mathrm{Cl}$. Net fluxes in microequivalents per hour per square centimeter were measured across short-circuited mucosa bathed in bicarbonate-Ringer. Concentrations of agents employed: EA, $0.1 \mathrm{mM}$ cAMP, $5 \mathrm{mM}$; theo, $10 \mathrm{mM}$. See legend to Table II for further details. Results for theo and cAMP have been pooled. 
TABLE III

Na Flux and SCC Responses to Glucose in the Presence and Absence of $E A$

\begin{tabular}{|c|c|c|c|c|c|}
\hline \multicolumn{2}{|c|}{ Additions } & \multicolumn{3}{|c|}{$\mathrm{Na}$} & \multirow[b]{2}{*}{$\mathrm{SCC}$} \\
\hline $\mathrm{EA}$ & Glucose & $\mathrm{J}_{\mathrm{m}} \mathrm{s}$ & $\mathrm{J}_{\mathrm{sm}}$ & $J_{\text {net }}$ & \\
\hline 0 & 0 & $12.4 \pm 0.6$ & $11.3 \pm 0.7$ & $1.1 \pm 0.3$ & $1.4 \pm 0.2$ \\
\hline \multirow[t]{2}{*}{0} & + & $14.8 \pm 1.0$ & $9.6 \pm 0.9$ & $5.1 \pm 0.8$ & $5.8 \pm 0.9$ \\
\hline & & \multicolumn{2}{|c|}{$\begin{array}{c}\text { Difference } \\
P<\end{array}$} & $\begin{array}{c}4.0 \pm 0.8 \\
0.01\end{array}$ & $\begin{array}{c}4.3 \pm 0.8 \\
0.01\end{array}$ \\
\hline+ & 0 & $10.2 \pm 0.8$ & $9.0 \pm 0.7$ & $1.2 \pm 1.0$ & $0.9 \pm 0.3$ \\
\hline \multirow[t]{2}{*}{+} & + & $16.2 \pm 0.6$ & $11.1 \pm 0.6$ & $5.1 \pm 0.3$ & $6.6 \pm 0.9$ \\
\hline & & \multicolumn{2}{|c|}{$\begin{array}{c}\text { Difference } \\
P<\end{array}$} & $\begin{array}{c}3.9 \pm 1.0 \\
0.05\end{array}$ & $\begin{array}{c}5.7 \pm 0.8 \\
0.005\end{array}$ \\
\hline
\end{tabular}

Values are means $\pm 1 \mathrm{SE}$ for five animals. Four tissues were mounted from each animal. EA, $0.1 \mathrm{mM}$ was added to the serosal bath of two and $10 \mathrm{mM}$ glucose was added to the luminal side of two. Glucose was added $20 \mathrm{~min}$ after EA and flux measurements begun $15 \mathrm{~min}$ thereafter. ${ }^{22} \mathrm{Na}$ and ${ }^{24} \mathrm{Na}$ bidirectional fluxes were determined simultaneously on all four tissues.

ever, this inhibition of toxin-induced $\mathrm{Cl}$ secretion was not observed. It is not clear whether $0.05 \mathrm{mM}$ is too low a concentration or whether a significant effect was obscured by the large statistical variability.

$\mathrm{EA}$, at $0.1 \mathrm{mM}$ concentration, also shifted net $\mathrm{Na}$ transport in the absorptive direction in the presence of both theophylline and cAMP. The increase in net $\mathrm{Na}$ flux was due to an increase in the unidirectional $\mathrm{J}_{\mathrm{ms}}$. Similar changes in $\mathrm{Na}$ transport were also produced by $0.05 \mathrm{mM} \mathrm{EA}$ in the presence of cholera toxin. However, at a $1.0 \mathrm{mM}$ concentration, EA failed to increase significantly net $\mathrm{Na}$ flux in the presence of cholera toxin. This concentration of EA also abolished the net $\mathrm{Na}$ flux of control tissues.

Effect of EA on glucose-coupled Na transport. The results shown in Table II indicate that $0.1 \mathrm{mM} \mathrm{EA}$, added on the serosal side, reverses cAMP-mediated active ion secretion. Since net $\mathrm{Na}$ absorption was observed in the presence of $0.1 \mathrm{mM} \mathrm{EA}$, the antisecretory effect of the diuretic does not appear to result from a general inhibition of all active ion transport. To examine the specificity of the secretory inhibition, the ability of glucose to augment $\mathrm{Na}$ transport in the presence of $0.1 \mathrm{mM}$ EA was tested. Results are shown in Table III. Glucose $(10 \mathrm{mM})$, added to the luminal bathing solution, produced equal increments of net $\mathrm{Na}$ flux in EA-treated and control tissues. These results suggest that $0.1 \mathrm{mM} \mathrm{EA}$ does not reduce the capacity of the Na pumping process.

Additional experiments, involving SCC measurements alone, were performed to determine if $1 \mathrm{mM} \mathrm{EA}$ would inhibit glucose-coupled $\mathrm{Na}$ transport. Mucosae were removed from cholera toxin-treated ileal loops and mounted in vitro. EA $(1 \mathrm{mM})$ was added to the serosal side of half of the tissues. $20 \mathrm{~min}$ later, glucose $(7.5 \mathrm{mM})$ was added to the luminal side of all tissues and the ensuing changes in SCC were recorded. In 10 experiments, the mean peak increment in $\mathrm{SCC}( \pm 1 \mathrm{SE})$ produced by glucose was $1.9 \pm 0.30 \mu \mathrm{eq} / \mathrm{h} \cdot \mathrm{cm}^{2}$ in EA-treated tissues and $1.6 \pm 0.15$ in control tissues. Since the increase in SCC which quickly develops after glucose is added to the luminal solution is largely or entirely due to an increase in active $\mathrm{Na}$ absorption (see Table III and references 11,15 , and 16 ), these data suggest that even $1 \mathrm{mM}$ EA does not inhibit the sodium-pumping capacity of the ileum.

Effect of EA on cAMP concentrations. The reported inhibitory effect of EA on intestinal mucosal adenyl cyclase activity (17) suggests one mechanism by which EA may inhibit cholera toxin-induced intestinal fluid secretion. To explore further the interaction of $\mathrm{EA}$ with cAMP metabolism in the ileal mucosa, sheets of mucosa preincubated with theophylline, purified cholera toxin. or Ringer's solution alone were exposed to $0.1 \mathrm{mM} \mathrm{EA}$ for periods ranging from 5 to $30 \mathrm{~min}$ and then processed for cAMP measurement. As shown in Table IV, $0.1 \mathrm{mM}$ EA did not significantly alter cAMP concentration.

\section{DISCUSSION}

The data presented in this report show that EA inhibits $\mathrm{Cl}$ secretion induced by prior addition of cAMP, the-

TABLE IV

Effect of EA on CAMP Levels in Cholera Toxin-Treated and Theophylline-Treated Rabbit Ileal Mucosa

\begin{tabular}{|c|c|c|c|c|}
\hline \multirow[b]{2}{*}{ Part A } & \multirow[b]{2}{*}{ Control } & \multicolumn{3}{|c|}{ ctMP Levels } \\
\hline & & EA & $\begin{array}{c}\text { Theo- } \\
\text { phylline }\end{array}$ & $\begin{array}{l}\text { Theo- } \\
\text { phylline }\end{array}$ \\
\hline & & \multicolumn{3}{|c|}{$\mathrm{pmol} / \mathrm{mg}$ protein } \\
\hline 1 & 7.9 & 6.2 & 16.6 & 23.7 \\
\hline 2 & 12.1 & 19.0 & 29.6 & 30.9 \\
\hline 3 & 7.4 & 6.0 & 14.6 & 16.2 \\
\hline 4 & 9.2 & - & 15.5 & 15.7 \\
\hline 5 & 10.5 & - & 25.6 & 31.1 \\
\hline Mean $\pm 1 \mathrm{SE}$ & $9.4 \pm 0.85$ & $10.4 \pm 4.3$ & $20.4 \pm 3.0$ & $2.3 .5 \pm 3.4 *$ \\
\hline Part B & Control & EA & Toxin & Toxin + EA \\
\hline 1 & 5.8 & 5.0 & 31.4 & 38.4 \\
\hline 2 & 4.9 & 4.4 & 16.3 & 21.5 \\
\hline 3 & 11.5 & 20.2 & 126.7 & 38.0 \\
\hline 4 & 23.0 & 10.5 & 12.3 .0 & 39.9 \\
\hline 5 & 4.8 & 8.9 & 15.2 & 19.7 \\
\hline 6 & 13.6 & 9.7 & 15.3 & 29.0 \\
\hline 7 & 8.9 & 10.7 & 29.5 & 31.0 \\
\hline Mean $\pm 1 \mathrm{SE}$ & $10.4 \pm 2.5$ & $9.9 \pm 2.0$ & $51.1 \pm 19.2$ & $31.1 \pm 3.1^{*}$ \\
\hline
\end{tabular}

In experiments 1-3, tissues were preincubated for $30 \mathrm{~min}$, then theophylline $(5 \mathrm{mM})$ was added to two flasks. $5 \mathrm{~min}$ thereafter, EA $(0.1 \mathrm{mM})$ was added to two flasks. Incubations were ended $5 \mathrm{~min}$ after $\mathrm{EA}$ addition. In experiments 4 and 5, EA was added $30 \mathrm{~min}$ after theophylline and incubations were ended $30 \mathrm{~min}$ after that. In part B, EA $(0.1 \mathrm{mM})$ was added $3 \mathrm{~h}$ after purified cholera toxin $(1 \mu \mathrm{g} / \mathrm{ml})$. Incubations were ended $30 \mathrm{~min}$ thereafter. * Significantly greater than control levels $(P<.01)$ but not significantly different from theophylline alone (part A) or cholera toxin alone (part B). 
ophylline, or cholera toxin. $\mathrm{NaCl}$ extrusion by rabbit kidney cortex slices has been shown to be inhibited by $\mathrm{EA}$ and it has been argued that this inhibition results from a generalized depression of cellular energy metabolism (18). Our data, especially at concentrations of EA less than $1 \mathrm{mM}$, suggest a more selective effect of the diuretic. cAMP-mediated active $\mathrm{Cl}$ secretion was inhibited by $\mathrm{EA}$ and active $\mathrm{Na}$ absorption was reestablished. Furthermore, the ability of glucose to further increase active $\mathrm{Na}$ absorption was not impaired. Thus the selective antisecretory effect of $0.1 \mathrm{mM} \mathrm{EA}$ indicated a clear separation between the active absorptive and secretory processes for ions in the ileum. Whether both processes occur in the same cell or each in different cells (i.e., secretion by crypt cells) remains unsettled.

Inhibition of active $\mathrm{Na}$ transport has been noted in everted hamster gut sacs after the addition of $5 \mathrm{mM} \mathrm{EA}$ to the serosal side (19) and in rabbit ileum after addition of $1 \mathrm{mM} \mathrm{EA}$ to the mucosal side (20). When added to the mucosal side, EA may accumulate inside the cell. This has been shown to occur in rat kidney cortex slices (21). Proverbio, Robinson, and Whittenbury (22) have found that $\mathrm{Na}$ (accompanied by $\mathrm{Cl}$ ) extrusion from kidney cortex slices is completely inhibited by 2 $\mathrm{mM} \mathrm{EA}$, a dose that has a minimal inhibitory effect on the Na-K-ATPase activity. It is noteworthy that the EA-sensitive ion transport process in kidney cortex slices appears to extrude both $\mathrm{Na}$ and $\mathrm{Cl}$ (23). It is clear then that the effect of EA on ion transport activity of various epithelia are of a more generalized nature at high concentrations whereas at lower concentrations (below $1 \mathrm{mM}$ ) processes possibly involving anions are more selectively affected.

$\mathrm{EA}$, in concentrations comparable with those used in the present study, has been shown to inhibit adenylate cyclase in both control and cholera toxin-treated intestinal mucosal homogenates (17). The present results indicate, however, that the mechanism by which $0.1 \mathrm{mM}$ EA inhibits secretion is clearly not through inhibition of adenylate cyclase since EA inhibited secretion produced by the direct addition of cAMP. Furthermore, the increase in intracellular cAMP level produced by cholera toxin and theophylline was not significantly altered. Whether $1 \mathrm{mM}$ EA would have affected cAMP levels was not determined. However, the change in net $\mathrm{Na}$ flux of cholera toxin-treated tissues produced by $0.05 \mathrm{mM}$ EA could not have resulted from an effect of EA on adenylate cyclase activity.

The nature of the antisecretory effect of EA remains to be elucidated. Since EA modified the effect of exogenously added cAMP, EA must interact more directly with the secretory process than does cAMP itself. In principle, its effect could be exerted on the $\mathrm{Cl}$ translocation process, on the supply of energy for the trans- port, or on the mechanism of coupling between the translocation process and metabolism. EA has been found to inhibit Na-K-ATPase in several tissues (2427). What role, if any, Na-K-ATPase plays in the intestinal secretory response is not known. Our data show that $0.1 \mathrm{mM}$ EA does not inhibit base-line $\mathrm{Na}$ absorption and, furthermore, that glucose-coupled $\mathrm{Na}$ transport is unimpaired. The latter strongly suggests that EA blocks $\mathrm{Cl}$ secretion without inhibiting the $\mathrm{Na}$ transport mechanism. Thus, with respect to Na-K-ATPase and $\mathrm{EA}$ inhibition of $\mathrm{Cl}$ secretion, there are three possibilities: (a) the antisecretory effect of EA is unrelated to ATPase inhibition; $(b)$ the coupling of energy to secretion involves a different and more EA-sensitive Na-K-ATPase than that which is linked to glucose-coupled $\mathrm{Na}$ transport; or $(c)$ the same $\mathrm{Na}$ $\mathrm{K}$-ATPase is required for both $\mathrm{Cl}$ secretion and glucosecoupled $\mathrm{Na}$ transport, but the former required a higher rate of enzyme activity than the latter. Recent investigations on ion transport in the thick ascending limb of the loop of Henle have shown that $\mathrm{Cl}$ is actively transported (28). This active transport is inhibited by furosemide (28) and also by EA and ouabain (29). Ouabain is thought to be a specific inhibitor of Na-KATPase. Clearly, more work needs to be done regarding the specific nature of active $\mathrm{Cl}$ transport, the factors that control it, and its relation, if any, to Na-K-ATPase.

Recent investigations on the effect of EA on energyyielding reactions show that in several systems, e.g., renal cortex (30), renal medulla (30), Ehrlich asictes tumor cells (31), and turtle bladder epithelium (30), EA was shown to affect a step in the glycolytic chain beyond formation of fructose diphosphate. In the turtle bladder, it was further demonstrated that EA inhibits glyceraldehyde-3-phosphate dehydrogenase activity (30). Whether cAMP stimulated $\mathrm{Cl}$ secretion by increasing the rate of glycolysis and, if so, whether glycolysis in the intestinal mucosa is inhibited by EA, are relevant questions that need to be answered.

\section{ACKNOWLEDGMENTS}

The authors are grateful to Dr. Richard A. Finkelstein, The University of Texas Southwestern Medical School, Dallas, Texas for his gift of purified cholera toxin.

This investigation was supported by the United StatesJapan Cooperative Medical Science Program administered by the National Institute of Allergy and Infectious Diseases of the National Institutes of Health (Grants AI 08209, AI 07625, and AI 09029) and by NIH Training Grant AM-05114.

\section{REFERENCES}

1. Field, M. 1971. Ion transport in rabbit ileal mucosa. II. Effects of cyclic 3',5'-AMP. Am. J. Physiol. 221: 992. 2. Field, M., D. Fromm, Q. Al-Awqati, and W. B. Greenough, III. 1972. Effect of cholera enterotoxin on 
ion transport across isolated ileal mucosa. J. Clin. Invest. $51: 796$

3. Sharp, G. W. G., and S. Hynie. 1971. Stimulation of intestinal adenyl cyclase by cholera toxin. Nature (Lond.). 229: 266.

4. Kimberg, D. V., M. Field, J. Johnson, A. Henderson, and E. Gershon. 1971. Stimulation of intestinal mucosal adenyl cyclase by cholera enterotoxin and prostaglandins. J. Clin. Invest. 50: 1218.

5. Schaefer, D. E., W. D. Lust, B. Sircar, and N. D. Goldberg. 1970. Elevated concentration of adenosine $3^{\prime}, 5^{\prime}$-cyclic monophosphate in intestinal mucosa after cholera toxin. Proc. Natl. Acad. Sci. U. S. A. 67: 851.

6. Guerrant, R. L., L. C. Chen, and G. W. Sharp. 1972. Intestinal adenyl-cyclase activity in canine cholera: Correlation with fluid accumulation. J. Infect. Dis. 125 : 377.

7. Frizzell, R. A., H. N. Nellans, R. C. Rose, L. Markscheid-Kaspi, and S. G. Schultz. 1973. Intracellular C1 concentrations and influxes across the brush border of rabbit ileum. Am. J. Physiol. 224: 328.

8. Nellans, H. N., R. A. Frizzell, and S. G. Schultz. 1973. Coupled sodium-chloride influx across the brush border of rabbit ileum. Am. J. Physiol. 225: 467.

9. Powell, D. W., H. J. Binder, and P. F. Curran. 1973. Active Electrolyte secretion stimulated by choleragen in rabbit ileum in vitro. Am. J. Physiol. 225: 781.

10. Carpenter, C. C. J., G. T. Curlin, and W. B. Greenough. 1969. Response of canine Thiry-Vella jejunal loops to cholera exotoxin and its modification by ethacrynic acid. J. Infect. Dis. 120: 332.

11. Field, M., D. Fromm, and I. McColl. 1971. Ion transport in rabbit ileal mucosa. I. $\mathrm{Na}$ and $\mathrm{Cl}$ fluxes and short-circuit current. Am. J. Physiol. 220: 1388.

12. Bray, G. A. 1960 . A simple efficient liquid scintillator for counting aqueous solutions in a liquid scintillation counter. Anal. Biochem. 1: 279.

13. Gilman, A. G. 1970. A protein binding assay for adenosine 3',5'-cyclic monophosphate. Proc. Natl. Acad. Sci. U. S. A. $67: 305$.

14. Lowry, O. H., N. J. Rosebrough, A. L. Farr, and R. J. Randall. 1951. Protein measurement with the folin phenol reagent. J. Biol. Chem. 193: 265.

15. Schultz, S. G., and P. F. Curran. 1970. Coupled transport of sodium and organic solutes. Physiol. Rev. 50: 637.

16. Schultz, S. G., and R. Zalusky. 1964. Ion transport in isolated rabbit ileum. II. The interaction between active sodium and active sugar transport. J. Gen. Physiol. $47: 1043$.
17. Sharp, G. W. G., S. Hynie, L. C. Lipson, and D. K. Parkinson. 1971. Action of cholera toxin to stimulate adenyl cyclase. Trans. Assoc. Am. Physicians Phila. $84: 200$.

18. MacKnight, A. D. C. 1969. The effects of ethacrynic acid on the electrolyte and water contents of rat renal cortical slices. Biochim. Biophys. Acta. 173: 223.

19. Binder, H. J., L. A. Katz, R. P. Spencer, and H. M. Spiro. 1966. The effect of inhibitors of renal transport on the small intestine. J. Clin. Invest. 45: 1854.

20. Chez, R. A., E. O. Horger, III, and S. G. Schultz. 1969. Effect of ethacrynic acid or sodium transport by isolated rabbit ileum. J. Pharmacol. Exp. Ther. 168: 1.

21. Epstein, R. W. 1972. Binding of ethacrynic acid to rabbit kidney cortex. Biochim. Biophys. Acta. 274: 119.

22. Proverbio, F., J. W. L. Robinson, and G. Whittenbury. 1970. Sensitivities of $\left(\mathrm{Na}^{+}-\mathrm{K}^{+}\right)-\mathrm{ATP}$ ase and $\mathrm{Na}^{+}$extrusion mechanisms to ouabain and ethacrynic acid in the cortex of the guinea-pig kidney. Biochim. Biophys. Acta. 211: 327.

23. Whittembury, G., and F. Proverbio. 1970. Two modes of $\mathrm{Na}$ extrusion in cells from guinea pig kidney cortex slices. Pfluegers Arch. Eur. J. Physiol. 316: 1.

24. Cassidy, M. M. 1970. Characteristics of the $\left(\mathrm{Na}^{+}-\mathrm{K}^{+}\right)$stimulated ATPase of rat jejunum. J. Physiol. (Lond.). 210: $153 \mathrm{P}$.

25. Charnock, J. S., H. A. Potter, and D. McKee. 1970. Ethacrynic acid inhibition of $\mathrm{Na}^{+}+\mathrm{K}^{+}$-activated adenosine triphosphatase. Biochem. Pharmacol. 19: 1637.

26. Davis, P. W. 1970. Inhibition of renal $\mathrm{Na}^{+}, \mathrm{K}^{+}$-activated adenosine triphosphatase activity by ethacrynic acid. Biochem. Pharmacol. 19: 1983.

27. Banerjee, S. P., V. K. Khanna, and A. K. Sen. 1971. Inhibition of sodium- and potassium-dependent adenosine triphosphatase by ethacrynic acid: ligand-induced modifications. Biochem. Pharmacol. 20: 1649.

28. Burg, M., L. Stoner, J. Cardinal, and N. Green. 1973. Furosemide effect on isolated perfused tubules. Am. J. Physiol. 225: 119.

29. Burg, M., and N. Green. 1973. Effect of diuretics on the thick ascending limb of Henle's loop. J. Clin. Invest. $52: 15 a$. (Abstr.)

30. Klahr, S., J. Yates, and J. Bourgoignie. 1971. Inhibition of glycolysis by ethacrynic acid and furosemide. $\mathrm{Am}$. J. Physiol. 221: 1038.

31. Gordon, E. E., and M. deHartog. 1969. The relationship between cell membrane potassium ion transport and glycolysis. The effect of ethacrynic acid. J. Gen. Physiol. $54: 650$. 